\author{
ACTA MYCOLOGICA \\ Vol. 43 (1): 21-27 \\ 2008
}

\title{
Fungi and fungi-like Oomycetes isolated from affected leaves of rhododendron
}

\author{
MARIA KOWALIK
}

Department of Plant Protection, University of Agriculture in Kraków

Al. 29. Listopada 54, PL-31-425 Kraków, mkowalik@ogr.ar.krakow.pl

Kowalik M.: Fungi and fungi-like Oomycetes isolated from affected leaves of rhododendron. Acta Mycol. 43 (1): 21-27, 2008.

The aim of the work is to identify fungi and fungi-like Oomycetes occurring on affected leaves of rhododendron Rhododendron L. Mycological analyses were carried out on 200 leaves collected from green areas of Kraków from May till September 2005. Isolated fungilike Oomycetes belonged to 67 taxa. The most frequently found fungi included: Alternaria alternata, Aspergillus niger, Botrytis cinerea, Coelophoma empetri, Nigrospora sphaerica, Pestalotia sydowiana, Phialophora cyclaminis, Phomopsis archeri, Septoria azalea and Sordaria fimicola. Among fungi-like organisms Phytophthora cinnamomi and P. citricola were isolated.

Key words: rhododendron, leaves, isolation, fungi-like Oomycetes

\section{INTRODUCTION}

Rhododendrons growing in urban green areas are susceptible to various pathogenes. Infected plants develop discolouration, brown spots and necroses, affecting their aesthetic value. The symptoms of infection, observable from spring to autumn, increase when the plants are in bloom resulting in dieback and leaf drop. The damage is caused by fungi-like Oomycetes of genera Pythium and Phytophthora and fungi of genera: Botrytis, Cercospora, Colletotrichum, Cylindrocladium, Exobasidium, Microsphaera, Ovulinia, Pestalotia, Phomopsis, Phyllosticta, Pycnostysanus, Ramularia, Rhizoctonia and Septoria (Farr et al. 1996; Werner, Kwaśna 1998; Werres 2000; Orlikowski 1999; Łabanowski et al. 2001; Kita, Mazurek 2003; Kowalik et al. 2006; Kowalik, Muras 2007).

The aim of this work was to identify the organisms occurring on affected rhododendron leaves in green areas of Kraków. 


\section{MATERIAL AND METHODS}

Leaves of rhododendron with the symptoms of discoloration, brown spots or necroses were collected from the plants in the Botanical Garden of the Jagiellonian University, the Zoological Garden and town lawns in Kraków. 200 leaves from 50 plants were collected for mycological analysis. The numbers of leaves taken from the top part (T), central part (C) and lower part (L) of the plant were approximately equal. The leaf samples were disinfected in $70 \%$ ethyl alcohol and 5 parts of each leaf from the area between ill and healthy tissue were put on Petri dishes with $2 \%$ PDA medium. The colonies of fungi and fungi-like Oomycetes were identified using various media for identification: Guba (1961), Domsch et al. (1980), Sutton (1980), Ho (1981), Ellis and Ellis (1987).

\section{RESULTS}

From the collected material 721 colonies of fungi, 19 colonies of fungi-like Oomycetes and 150 colonies of bacteria (not being the subject of this paper) were isolated. The isolated fungi and Oomycetes belonged to 67 taxa within 37 genera.

Among the dominat fungi the following constitued more than 66 per cent of the total: Alternaria alternata, Aspergillus niger, Botrytis cinerea, Cladosporium macrocarpum, Coelophoma empetri, Humicola grisea v. grisea, Nigrospora sphaerica, Pestalotia sydowiana, Phialophora cyclaminis, Ph. richardsiae, Phoma fimeti, Ph. macrostoma, Phomopsis archeri, Pycnostysanus azaleae, Septoria azalea and Sordaria fimicola. Less frequent were: Acremonium furcatum, Cladosporium sphaerospermum, Colletotrichum gloeosporioides, Cylindrocladium scoparium, Epicoccum purpurascens, Exobasidium vaccinii, Humicola fuscoatra v. fuscoatra, Phoma chrysanthemicola and Ph. putaminum. Fungi belonging to 20 taxa occurred once or twice.

Fungi-like Oomycetes were represented by Phytophthora cinnamomi and Ph. citricola (Tab. 1).

Among the species isolated from the leaves situated in the central part of the plants, the following were predominant: A. alternata, B. cinerea, C. empetri, C. gloeosporioides, E. purpurascens, N. sphaerica, P. sydowiana, S. fimicola and fungi belonging to genera: Aspergillus, Chaetomium, Cladosporium, Humicola and Penicillium.

From leaves situated in the lower parts of the plant, the following were isolated: Cylindrocarpon destructans, C. scoparium, Ph. archeri, Rhizoctonia solani, S. fimicola, Trichothecium roseum and fungi of genera: Acremonium, Fusarium, Mortierella and Phialophora. From the lower parts also Ph. cinnamomi and Ph. citricola were isolated.

From the leaves situated at the top part of the plant, numerous colonies of A. alternata, C. empetri, S. azalea, S. fimicola were isolated. Less frequent were: E. vaccinii, Mucor hiemalis, P. sydowiana, Pycnostysanus azaleae and fungi of genera Trichoderma and Phoma.

The frequency of species occurrence of fungi and fungi-like Oomycetes on leafblades was differentiated. The following species occurred at the highest frequency: A. alternata, S. fimicola, P. sydowiana, S. azalea and C. empetri. They were isolated (respectively) from 27, 11, 9, 8 and 7 leaves. Less frequently (on 5-6 leaves) occurred:Aspergillus niger, B. cinerea, Cladosporium macrocarpum, C. gloeosporioides, 
Table 1

Fungi and fungi-like Oomycetes isolated from affected leaves of rhododendron

\begin{tabular}{|c|c|c|c|c|}
\hline Species & $\begin{array}{c}\text { Fre- } \\
\text { quency } \\
\text { of occur- } \\
\text { rence }\end{array}$ & $\begin{array}{l}\text { Percent- } \\
\text { age of } \\
\text { occur- } \\
\text { rence }\end{array}$ & $\begin{array}{l}\text { The } \\
\text { number } \\
\text { of leaves } \\
\text { the fun- } \\
\text { gus spe- } \\
\text { cies was } \\
\text { isolated } \\
\text { from }\end{array}$ & $\begin{array}{c}\text { Localiza- } \\
\text { tion of } \\
\text { leaves* }\end{array}$ \\
\hline Acremonium butyri (van Beyma) W. Gams & 6 & 0.81 & 2 & $\mathrm{~L}$ \\
\hline Acremonium furcatum F. et V. Moreau ex W. Gams & 8 & 1.08 & 2 & $\mathrm{~L}$ \\
\hline Acremonium fusidioides (Nicot) W. Gams & 1 & 0.14 & 1 & $\mathrm{C}$ \\
\hline Acremonium kiliense Grütz & 4 & 0.54 & 1 & $\mathrm{~L}$ \\
\hline Alternaria alternata (Fr.) Keissler & 131 & 17.70 & 27 & TCL \\
\hline Arthrinium pheosphermum (Corda) M. B. Ellis & 2 & 0.27 & 1 & $\mathrm{C}$ \\
\hline Aspergillus niger van Tiegh. & 21 & 2.84 & 6 & $\mathrm{C}$ \\
\hline Aspergillus wentii Wehmer & 4 & 0.54 & 1 & $\mathrm{C}$ \\
\hline Botrytis cinerea Pers. ex Nocca et Balb. & 21 & 2.84 & 6 & $\mathrm{C}$ \\
\hline Chaetomium globosum Kunze ex Steud. & 3 & 0.41 & 1 & $\mathrm{C}$ \\
\hline Chaetomium indicum Corda & 2 & 0.27 & 1 & $\mathrm{C}$ \\
\hline Chrysosporium asperatum Carm. & 6 & 0.81 & 2 & $\mathrm{C}$ \\
\hline Chrysosporium merdarium (Link ex Grev.) Carm. & 1 & 0.14 & 1 & $\mathrm{~L}$ \\
\hline Cladosporium cladosporioides (Fres.) de Vries & 6 & 0.81 & 2 & $\mathrm{C}$ \\
\hline Cladosporium macrocarpum Preuss & 19 & 2.57 & 6 & $\mathrm{C}$ \\
\hline Cladosporium sphaerospermum Penz. & 10 & 1.35 & 2 & $\mathrm{C}$ \\
\hline Coelophoma empetri (Rostr.) Petrak & 25 & 3.38 & 7 & TC \\
\hline Colletotrichum gloeosporioides (Penz.) Sacc. & 14 & 1.89 & 5 & $\mathrm{C}$ \\
\hline Coniothyrium minitans W. A. Campbell & 6 & 0.81 & 2 & $\mathrm{C}$ \\
\hline Cylindrocarpon destructans (Zins.) Scholten & 6 & 0.81 & 2 & $\mathrm{~L}$ \\
\hline Cylindrocarpon tenue Bugn. & 2 & 0.27 & 1 & $\mathrm{C}$ \\
\hline Cylindrocladium scoparium Morg. & 8 & 1.08 & 2 & $\mathrm{~L}$ \\
\hline Doratomyces stemonitis (Pers. ex Steud.) Morton & 2 & 0.27 & 1 & $\mathrm{~T}$ \\
\hline Epicoccum purpurascens Ehrenb. ex Schlecht. & 12 & 1.62 & 4 & $\mathrm{C}$ \\
\hline Exobasidium vaccinii (Fuckel) Woron. & 12 & 1.62 & 3 & $\mathrm{~T}$ \\
\hline Fusarium culmorum (W. G. Sm.) Sacc. & 5 & 0.68 & 1 & $\mathrm{~L}$ \\
\hline Fusarium graminearum Schwabe & 2 & 0.27 & 1 & $\mathrm{~L}$ \\
\hline Fusarium stilboides Wollenw. & 2 & 0.27 & 1 & $\mathrm{~L}$ \\
\hline Gloeosporium rhododendri Briosi et Cav. & 2 & 0.27 & 1 & $\mathrm{C}$ \\
\hline Humicola fuscoatra Traaen var. fuscoatra & 8 & 1.08 & 4 & $\mathrm{C}$ \\
\hline Humicola grisea Traaen var. grisea & 17 & 2.30 & 5 & $\mathrm{C}$ \\
\hline Mammaria echinobotryoides Ces. & 7 & 0.95 & 2 & $\mathrm{C}$ \\
\hline Morenoina rhododendri J. P. Ellis & 2 & 0.27 & 1 & $\mathrm{C}$ \\
\hline Mortierella alpina Peyronel & 2 & 0.27 & 1 & $\mathrm{~L}$ \\
\hline Mortierella horticola Linnem. & 1 & 0.14 & 1 & $\mathrm{~L}$ \\
\hline Mortierella isabellina Oudem. & 1 & 0.14 & 1 & $\mathrm{~L}$ \\
\hline Mortierella parvispora Linnem. & 4 & 0.54 & 1 & $\mathrm{~L}$ \\
\hline Mucor hiemalis Wehmer f. hiemalis & 4 & 0.54 & 1 & $\mathrm{~T}$ \\
\hline Myrothecium cinctum (Corda) Sacc. & 1 & 0.14 & 1 & $\mathrm{C}$ \\
\hline Nectria inventa Pethybr. & 2 & 0.27 & 1 & $\mathrm{C}$ \\
\hline Nigrospora sphaerica (Sacc.) Mason & 21 & 2.84 & 5 & $\mathrm{C}$ \\
\hline Penicillium expansum Link ex Gray & 7 & 0.95 & 2 & $\mathrm{C}$ \\
\hline Pestalotia sydowiana Bres. & 40 & 5.41 & 9 & $\mathrm{TC}$ \\
\hline Phialophora cyclaminis van Beyma & 23 & 3.11 & 5 & $\mathrm{~L}$ \\
\hline Phialophora richardsiae (Nannf.) Conant & 16 & 2.16 & 4 & $\mathrm{~L}$ \\
\hline Phoma chrysanthemicola Hollòs & 11 & 1.49 & 3 & $\mathrm{~T}$ \\
\hline Phoma epicoccina Punithalingam, Tulloch et Leach & 7 & 0.95 & 2 & $\mathrm{~T}$ \\
\hline Phoma eupyrena Sacc. & 6 & 0.81 & 2 & $\mathrm{~T}$ \\
\hline
\end{tabular}


Tab. 1 cont.

\begin{tabular}{|l|c|c|c|c|}
\hline Phoma fimeti Brun. & 18 & 2.43 & 6 & $\mathrm{~T}$ \\
\hline Phoma herbarum Westd. & 3 & 0.41 & 1 & $\mathrm{~T}$ \\
\hline Phoma leveillei Boerema et Bollen & 1 & 0.14 & 1 & $\mathrm{~T}$ \\
\hline Phoma macrostoma Mont. & 17 & 2.30 & 6 & $\mathrm{~T}$ \\
\hline Phoma medicaginis Malbr. et Roum. & 5 & 0.68 & 1 & $\mathrm{~T}$ \\
\hline Phoma pomorum Thüm. & 5 & 0.68 & 1 & $\mathrm{~T}$ \\
\hline Phoma putaminum Speg. & 9 & 1.22 & 2 & $\mathrm{~T}$ \\
\hline Phomopsis archeri Sutton & 23 & 3.11 & 6 & $\mathrm{~L}$ \\
\hline Phytophthora cinnamomi Rands & 12 & 1.62 & 3 & $\mathrm{~L}$ \\
\hline Phytophthora citricola Sawada & 7 & 0.95 & 2 & $\mathrm{~L}$ \\
\hline Pseudeurotium zonatum van Beyma & 2 & 0.27 & 1 & $\mathrm{C}$ \\
\hline Pycnostysanus azaleae (Peck) E. Mason & 16 & 2.16 & 5 & $\mathrm{~T}$ \\
\hline Rhizoctonia solani Kühn & 2 & 0.27 & 1 & $\mathrm{~L}$ \\
\hline Septoria azalea Voglino & 33 & 4.46 & 8 & $\mathrm{~T}$ \\
\hline Sordaria fimicola (Rob.) Ces. et de Not. & 53 & 7.16 & 11 & $\mathrm{TCL}$ \\
\hline Trichoderma harzianum Rifai & 2 & 0.27 & 1 & $\mathrm{~T}$ \\
\hline Trichoderma pseudokoningii Rifai & 2 & 0.27 & 1 & $\mathrm{~T}$ \\
\hline Trichoderma viride Pers. ex Gray & 4 & 0.54 & 1 & $\mathrm{~T}$ \\
\hline Trichothecium roseum (Pers.) Link ex Gray & 3 & 0.41 & 1 & $\mathrm{~L}$ \\
\hline Total & 740 & 100.00 & - & - \\
\hline
\end{tabular}

Abbreviations: * - localization of leaves: $\mathrm{T}$ - top part of the plant; $\mathrm{C}$ - central part of the plant; $\mathrm{L}$ - lower part of the plant.

Humicola grisea v. grisea, N. sphaerica, Ph. cyclaminis, Ph. fimeti, Ph. macrostoma, $P h$. archeri and P. azaleae. On 3-4 leaves occurred E. purpurascens, E. vaccinii, $H$. fuscoatra v. fuscoatra, Ph. richardsiae, Ph. chrysanthemicola and Ph. cinnamomi. The remaining were isolated form 1-2 leaves (Tab. 1).

Rhododendron symptoms caused by fungi and fungi-like Oomycetes were varied. From chlorosis affected leaves with discoloration changes alongside the main veins, $C$. destructans, $C$. tenue, $C$. scoparium, and also three species of Fusarium were isolated. Fungus $R$. solani, causing the rhizoctoniosis in rhododendron, was isolated from the leaves with irregular brown-grey spots, surrounded by a large yellow area. B. cinerea, the cause of Botrytis petal blight, was isolated from rapidly dying leaves, with the symptoms of necrosis, such as large brown spots covered with dense grey mould. Fungus $E$. vaccinii, was isolated from deformed leaves with small reddish and brownish galls, typical of azalea leaf and flower gall. The cause of large oval necrotic spots with dark linings and visible picnidia was identified as Ph. archeri.

Other pathogens occurring in phyllosphere, such as $C$. gloeosporioides (causing rhododendron anthracnose), Gloeosporium rhododendri, Morenoina rhododendri, C. empetri and S. azalea (the reason for leaf scorch) caused round, oval or irregular necrotic spots of different shapes. A sign of $C$. gloeosporioides infection was grey spots, with visible rings and picnidia. In case of $S$. azalea, small oval, grey-brown spots with darker lining were seen. Necrotic spots caused by Ph. cyclaminis and $P$. richardsiae were small irregular with uneven edges. $P$. sydowiana was isolated from large light brown necrotic spots appearing on the edges and the tops of the leaves.

Leaf petioles and blades, with brown discolouration and necroses forming a cline shape, were the reflection of $P h$. cinnamomi and $P h$. citricola presence. These pathogens were also isolated from fast expanding brown oval spots along the leaf margin. 


\section{DISCUSSION}

Different discolorations, brown spots and necroses, visible on rhododendron leaves in green areas of Kraków, were caused by many organisms classified as Fungi and Oomycetes. According to Farr et al. (1996), Werner and Kwaśna (1998), Werres et al. (2000), Łabanowski et al. (2001) rhododendron leaves can be infected by fungi and fungi-like organisms of different genera including: Botrytis, Cercospora, Colletotrichum, Cylindrocladium, Exobasidium, Gloeosporium, Macrophoma, Microsphaera, Monochaetia, Pestalotia, Pestalotiopsis, Phomopsis, Phyllosticta, Phytophthora, Septoria, Rhizoctonia and others. While Kita and Mazurek (2003) isolated fungi of genera: Alternaria, Botrytis, Cladosporium, Epicoccum, Fusarium, Humicola, Mucor, Penicillium, Pestalotia, Phoma, Rhizopus, Sclerotinia and Trichoderma from the phyllosphere of rhododendron and azalea growing in the botanical garden and arboretum. This research work confirms that most of fungi and fungilike Oomycetes isolated from the affected leaves of rhododendron belong to the mentioned above taxa.

The determination of organisms inhabiting affected rhododendron leaves enabled to show the relation between pathogens and pathologic symptoms. The isolation of fungi such as: $C$. destructans, $C$. tenue, $C$. scoparium in the leaves with the discolouration alongside the main vein indicates that the root system of the plants was firsty attacked, causing root rot, as mentioned by Werner (2005) and Labanowski et al. (2001). Also in the work by Kowalik and Muras (2007) fungi C. destructans, C. scoparium and numerous species of Fusarium were numerously isolated from dropped rhododendron leaves. Fungus $R$. solani was the reason for rhododendron rhizoctoniosis, $B$. cinerea caused grey mould, C. gloeosporioides - anthracnose, and S. azalea - rhododendron leaf scorch (Labanowski et al. 2001), while fungus $E$. vaccinii spending winter in flower and leaf buds of rhododendrons, in spring caused the disease called azalea leaf and flower gall (Orlikowski 1999).

The occurrence in phyllosphere of pathogens such as C. gloeosporioides, G. rhododendri, M. rhododendri, C. empetri and S. azalea (numerously isolated in this reasearch work) and leaf symptoms caused by them were documented in the papers by Werner and Kwaśna (1998), Łabanowski et al. (2001), Kita and Mazurek (2003).

In this work $P$. sydowiana was frequently isolated. Labanowski et al. (2001) do not attribute necroses to this species. The role of $P$. sydowiana in causing necroses of heathers in nurseries and in permanent sites was described by Kowalik and Sagan (2005) as well as Kowalik and Wandzel (2005), while Kita and Mazurek (2003), in phyllosphere of azaleas and rhododendrons found quite numerously occurring: Pestalotia fibricola, $P$. rhododendrii and $P$. truncata. In the works by Kowalik and Muras (2007) fungus $P$. sydowiana together with $A$. alternata, occurred causing spots and necroses of rhododendron leaves and intensifying the process of leaf drop were isolated at large frequency.

The description of phytophtorosis symptoms on leaves and petioles of rhododendrons and their effects in rhododendron plantings are confirmed in the works by Łabanowski et al. (2001), Werres (2000), Werner (2005), Kowalik et al. (2006). The occurrence of $P h$. citricola in rhododendron nurseries and susceptibility of many rhododendron taxa to this pathogen is described by Orlikowski and Szkuta (2003), 
while Orlikowski and Szkuta (2002) highlight the role Ph. cinnamomi in causing phytophtorosis on container-grown ericaceous plants in ornamental nurseries.

While analysing the plant material, it was found out that, in addition to the above mentioned causes of discolorations, brown spots and necroses, the secondarily invading fungi on pathological leaves were identified. They were the following: A. alternata, S. fimicola, N. sphaerica, A. niger and the species of genera: Acremonium, Cladosporium, Humicola, Mortierella, Mucor, Penicillium, Phoma and Trichoderma. According to Werner and Kwaśna (1998) these fungi can intensify pathogenic processes. Inhabiting small necrotic areas in a short time they rapidly intensify the process of necrosis. A large participation of fungi from genera: Alternaria, Cladosporium, Epicoccum and Phoma in the phyllosphere of rhododendrons is mentioned by Kita and Mazurek (2003). Their work indicates that these saprotrophs dominate in the structure of the populations of isolated fungi. The obtained results confirm considerable participation of $A$. alternata, E. purpurascens, $C$. macrocarpum, C. sphaerospermum and many species of Phoma in the populations of fungi isolated from necrotic tissues of rhododendrons.

It can be concluded that a large biodiversity of fungi and fungi-like Oomycetes isolated from the affected rhododendron leaves in the green areas of Kraków caused different pathologic symptoms and decreased decorative value of the plants.

\section{CONCLUSIONS}

1. The most numerous fungi occurring in the rhododendron plantings in the green areas of Kraków were: Alternaria alternata, Aspergillus niger, Botrytis cinerea, Coelophoma empetri, Nigrospora sphaerica, Pestalotia sydowiana, Phialophora cyclaminis, Phomopsis archeri, Septoria azalea and Sordaria fimicola

2. Among the fungi-like Oomycetes Phytophthora cinnamomi and Ph. citricola were isolated from the affected rhododendron leaves.

3. The causes of discolorations, brown spots and necroses of the rhododendron leaves were the pathogens belonging to genera: Botrytis, Colletotrichum, Cylindrocarpon, Cylindrocladium, Exobasidium, Fusarium, Pestalotia, Phomopsis, Phytophthora, Rhizoctonia and Septoria.

4. Commonly occurring saprotrophs of genera: Acremonium, Alternaria, Cladosporium, Coelophoma, Epicoccum, Humicola, Nigrospora, Phoma, Sordaria and others, intensified the process of leaf necrosis.

5. On the rhododendron plants the symptoms of phytophthorosis, grey mould, rhizoctoniosis, anthracnose, leaf scorch, azalea leaf and flower gall were found. The effect was leaf drop and, in consequence decreased decorative value of the plants.

\section{REFERENCES}

Domsch K. H., Gams W., Anderson T. H. 1980. Compendium of soil fungi. Acad. Press. London, New York, Toronto, Sydney, San Francisco.

Ellis M. B., Ellis J. P. 1987. Microfungi on land plants. Croom Helm. London, Sydney.

Farr D., Esteban H. B., Palm M. E. 1996. Fungi on Rhododendron: a world reference. Parkway Publish., Bonne, NC.

Guba E. F. 1961. Monograph of Monochaetia and Pestalotia. Harvard Univ. Press, Cambrige.

Ho H. H. 1981. Synoptic keys to the species of Phytophthora. Mycologia 73: 705-714. 
Kita W., Mazurek J. 2003. Skład gatunkowy fyllosfery różaneczników w Ogrodzie Botanicznym we Wrocławiu i w Arboretum w Wojsławicach. Erica Polonica 14: 25-36.

Kowalik M., Sagan A. 2005. Fungi causing dying out heather in permanent plantings. Acta Mycol. 40 (2): 191-195.

Kowalik M., Wandzel A. 2005. Grzyby powodujące zamieranie sadzonek wrzosu. Acta Agrobot. 58 (2): 237-242.

Kowalik M., Muras P. 2007. Grzyby zasiedlające opadłe liście różanecznika. Rocz. AR w Poznaniu 383. Ogrodnictwo 41: 69-73.

Kowalik M., Oliwa A., Paliga A. 2006. Choroby różaneczników (Rhododendron L.) na terenach zieleni Krakowa. Erica Polonica 17: 33-41.

Łabanowski G., Orlikowski L., Soika G., Wojdyła A., Korbin M. 2001. Ochrona roślin wrzosowatych. Plantpress.

Orlikowski L. B. 1999. Powłocznik azaliowy na azalii i różaneczniku. Ochrona Roślin 2:12.

Orlikowski L. B., Szkuta G. 2002. Occurrence of Phytophthora cinnamomi on ericaceous plants in container-grown ornamental nurseries in Poland. J. Plant Protect. Res. 42 (2): 157-163.

Orlikowski L. B., Szkuta G. 2003. Phytophthora citricola on Rhododendron spp. in Polish nurseries. J. Plant Protect. Res. 43 (1): 19-24.

Sutton B. C. 1980. The Coelomycetes. CMI, Kew, Surrey.

Werner M. 2005. Grzyby zasiedlające korzenie różaneczników w szkółkach i ich znaczenie dla zdrowotności roślin. Erica Polonica 16: 65-72.

Werner M., Kwaśna H. 1998. Choroby pędów i liści różanecznika. Ochrona Roślin 8: 10-11.

Werres S. 2000. Phytophthora spp. an Rhododendron und Azaleen. (In:) J.Westhoff (ed.). Rhododendron und immergrüne Laubgehölze. Jahrbuch der Deutschen Rhododendron Gesselschaft 1999: 99-113.

\section{Grzyby i organizmy grzybopodobne Oomycetes wyizolowane z porażonych liści różanecznika}

Streszczenie

Celem pracy była identyfikacja grzybów i organizmów grzybopodobnych Oomycetes występujących na porażonych liściach różanecznika Rhododendron L. Materiał do badań stanowiło 200 liści (z objawami przebarwień, plamistości i nekroz) zebranych z 50 krzewów na terenie Ogrodu Botanicznego UJ, Ogrodu Zoologicznego oraz na skwerkach miejskich Krakowa. Wyodrębniono grzyby i organizmy grzybopodobne Oomycetes (w liczbie 740 kolonii), należące do 67 taksonów. Na porażonych liściach najliczniej występowały grzyby: Alternaria alternata, Aspergillus niger, Botrytis cinerea, Coelophoma empetri, Nigrospora sphaerica, Pestalotia sydowiana, Phialophora cyclaminis, Phomopsis archeri, Septoria azalea i Sordaria fimicola. Spośród organizmów grzybopodobnych, z porażonych liści różanecznika wyizolowano Phytophthora cinnamomi i Ph. citricola. Sprawcami przebarwień, plamistości i nekroz na liściach różanecznika były patogeny z rodzajów: Botrytis, Colletotrichum, Cylindrocarpon, Cylindrocladium, Exobasidium, Fusarium, Pestalotia, Phomopsis, Phytophthora, Rhizoctonia i Septoria. Licznie występujące saprotrofy z rodzajów: Acremonium, Alternaria, Cladosporium, Coelophoma, Epicoccum, Humicola, Nigrospora, Phoma, Sordaria i inne intensyfikowały proces nekrotyzacji liści. Na różanecznikach rozpoznano objawy fytoftorozy, szarej pleśni, rizoktoniozy, antraknozy, septoriozy, powłocznika azaliowego, w wyniku których dochodziło do zamierania i opadania liści, a tym samym obniżenia walorów dekoracyjnych roślin. 